\title{
Torture Museums: What Has Changed Today?
}

\author{
Rüçhan Gökdağ \\ Anadolu University, Eskişehir, Turkey
}

\begin{abstract}
Torture has always been regarded as a tool for confession and applied throughout history. In cases when requesting and convincing do not work, threatening or torturing has been considered to be a "right" to do. Torture was used in Ancient Rome, in Europe in Medieval Age, and in England even though it was against unwritten law, and applied in USA secretly today. Since ancient times, people have been used to torturing for similar purposes. Today, torture is put into practice again for similar purposes such as forcing people to live according to religious beliefs and looking after the benefits of the government. Torture museums found in many European countries make visitors confused as these museums display terrifying tools applied to the Christian community in Medieval Age and then used by Christians to torture "Deviants".
\end{abstract}

Keywords: Torture, torture museums, torture tools, torture in Monotheistic Religions

\section{Introduction}

Torture probably first appeared on animals and on the enemies of a tribe or a race. Following this, purposes of torture gradually varied, and new torturing techniques were invented. As the rule that tolerating one thing today will soon turn into approval of that thing is also valid for torturing, people's indifference to torture and even their tolerance towards it resulted in justifying torture.

Torture appeared due to the need for finding a victim in the name of the society and God. Such justifications not only function as a suppression or prevention of the feeling of injustice in the society but also caused the thought of punishment to take place among all members of the society. In this respect, it has always been easy to justify all kinds of vandalism, and for centuries, most violent investigations and torments have been defended and put into practice.

Torture museums are extremely interesting places which accommodate tools used to make people feel pain and sadness. Torture museums in Europe are also places that draw people's attention not only with their torture tools previously used and related drawings and photos but also with their indoor organization of the environment. In addition, these museums inform people about past experiences of people of that time and allow making evaluations regarding the present time. This paper presents the effects of the museums I visited in Far East as well as in several countries in Europe on me and the similarities between the torture of today and that of the past. Below is first the definition of torture and then some information about types of torture. Following this, the paper focuses on principles of torture and on how monotheistic religions view torture. Lastly, the murders committed today for the sake of the government and in the name of Islam and the torture tools used in Medieval Age and displayed in torture museums are illustrated.

Rüçhan Gökdağ, Associate Professor, Department of Communication Design and Management, Faculty of Communication Sciences, Yunus Emre Campus, Anadolu University. 


\section{What is Torture?}

The most widely accepted definition of torture internationally is the one set out by the United Nations Convention Against Torture and other Cruel, Inhuman or Degrading Treatment or Punishment:

..."torture" means any act by which severe pain or suffering, whether physical or mental, is intentionally inflicted on a person for such purposes as obtaining from him or a third person information or a confession, punishing him for an act he or a third person has committed or is suspected of having committed, or intimidating or coercing him or a third person, or for any reason based on discrimination of any kind, when such pain or suffering is inflicted by or at the instigation of or with the consent or acquiescence of a public official or other person acting in an official capacity. It does not include pain or suffering arising only from, inherent in or incidental to lawful sanctions. ${ }^{1}$

\section{Kinds of Torture}

Torture is any type of action taken consciously for punishment and revenge purposes via either physical or psychological threat to make people suffer. There is different kind of tortures:

- Physical torture is making use of physical pain to have the victim suffer from torment. This was the most common type of torture.

- Psychological torture is making use of psychological pain to have the victim suffer from torment. Its effects are not visible to others. Rather than non-physical methods, mental, emotional and psychological methods are used to have the victim suffer from pain. Psychological torture could result in serious heart-related illnesses and even in death. However, this kind of physical results may not generally be the intended consequence. In contrast, death usually contradicts with the ultimate goal since is doesn't allow the torture last long and thus doesn't make the victim feel more pain.

- Psychiatric torture, in order to torture wise people for political, religious or family-related reasons, psychiatric diagnosis and related treatments were used. This type of torture was frequently used in Soviet Russia on political captives. Its softer types were applied on military officers who did not obey the commands in the American army. Some religious groups of people, who wanted to get rid of problem members diagnosed wise people as mentally retarded and tried to make psychiatric torture on these members by constantly condemning them.

- Pharmacological torture, using psychotropic and/or other types of chemicals on victims to torment them as well as to have them comply with the purposes of torture.

- Porn-torture, forcing the victim to have sex in public and to video-record the action. In this type of torture, the victim is subjected consciously to physical and mental pain for investigation and punishment purposes.

\section{Basic Principles of Torture}

Scot, in his sudy titled The History of Torture throughout the Ages explains the principles of torture under four headings (1959, p. 10).

\section{The Main Tool for Taking Revenge}

With its basic and universal definition, it is the easiest and simplest and most effective and satisfactory method of taking revenge for individuals. It would not be an exaggeration to say that all men and women have the potential of being a torturer. The basic reason for the popularity and spread of torture in every era is the fact that it wasnt regarded as torture by individuals, the society or the government applying it Torture has a

\footnotetext{
${ }^{1}$ Retrieved from http://www.irct.org/.
} 
relationship with the feeling of punishment developed by individuals who think they, their families or their governments are subjected to injustice or to an assault. The ambition for taking revenge leads to the desire to make a criminal to feel pain before death.

\section{Reflection of the Authority and of Power}

The underlying reason for the feeling of taking revenge in torture is to show the power of the government and to govern like a dictator. As an extension of an individual's desire to take revenge, satisfying a group or a community's feeling of taking revenge has been adopted by the leading people and has been made a part of their policies. The most valid and powerful tool for struggling with religious deviance and with crimes considered to be a betrayal to the government is today torturing as it used to be.

\section{Hatred Psychology}

Even if a person's opponents, or rivals, belong to his or her own race, they are always considered to be potential enemies. Similarly, a powerful neighboring country can be assumed to an enemy. All people and all things, considered to be a danger, are issues of potential hatred. As the fear of an opponent or a competitor develops, enmity will naturally grow, which will then increase the probability of torturing. The reason is that protection requires taking action.

Potential existence of hatred leads to occurrence of conscious or unconscious gangs, organizations, troops and groups to protect oneself. Similarly, it may also result in international agreements, conventions and assemblies, and this tendency is gradually increasing today.

\section{Social Tolerance of Torture}

Some people in a society have always believed in the virtues of torture. In their actions and expressions, they claim that one should obey religion or governmental bodies. Sumner (1907), saying that "it should not be forgotten that it was the public who first applied capital punishment by burning those who reacted against the church" (p. 238 cited in Scot, 1959, p. 26), stated that crowds lynched the deviants before the church started inquiring them. The primitive feeling of taking revenge constitutes the basis of this reaction of people. Because of this collective feeling, inquisition courts could be said to adopt this method to make people confess. Familiarity with torture will result in approving torture, which will then end up with justifying torture.

Inhuman behavior towards an acquaintance that will cause anger will not be objected to if that behavior is demonstrated towards a person hated. Also, when the conditions are provocative, this kind of behavior will even be supported. Cruel torments applied on strangers who are thought to be an enemy and who behave on the contrary to their gender are tolerated and approved.

\section{Public Psychology}

When the society once starts torturing, it is inevitable for this torture to continue and spread. Limiting the initial applications of torture to the actions considered to be dangerous in terms of ethics and religion did not hinder its repetition and its spread. In contrast, this led to destruction of deviants, antagonists and administrators. Tolerating and approving this type of torment resulted in viewing it not as a torture but as a punishment. This situation which started hundreds of centuries ago has reached the present time and become one of the important factors for torture to continue. Cruel ways of punishment met with sympathy by Medieval Age judges continue their existence as today's ordinary methods. 


\section{History of Torture}

This study does not aim at giving the history of torture, but to answer the question of "What has changed?" directed in the title, it is necessary to look at the history of torture from the bird's-eye-view. Throughout history, torture has been applied in a way appropriate to the same model. One important feature of this model is related to the purpose of torture: The basic purpose of torture is to make the person confess and to obtain the information desired. The confession should not necessarily reflect the truth. The mere purpose is to justify the torment and to punish the suspect. Torture aims at neither securing the justice nor revealing the fact.

Secondly, the torturer is always the powerful side, and due to the torment applied by this side is respected, admired and considered successful — at least by some part of the society. As for the weak side, they are tormented and humiliated. The oppressor's cruelty can only be defeated by a more powerful side. As long as they were powerful, Romans used to torture Christians. When Rome collapsed and Christianity rose, this time, Christians tormented those from other religions.

\section{Monotheistic Religions and Torture}

All monotheistic religions used torture as a religious or ritual method of punishment. As can be clearly understood from the numerous statements found in old-testament, Yehova, the God of Israel, applied suppressed beliefs with cruelty, terrorism and fear (Scot, 2001). In the religion of Christianity, especially deviance, the crime committed against the God, was known by everyone to be the most frightening crime. A person suspected of deviance used to be believed to deserve the most violent punishment, and proving his or her innocence was of vital importance. In order to find the related evidence for innocence, all kinds of tools applied to make the suspect confess were considered to be legitimate.

Any kind of disaster was enough to make people believe that there was a deviant among them. They do their best to find a person to blame. When they found a suspect, they used to torture until they made him or her confess and before the Church or the Government took action. In the end, they used to tie the suspect to a wooden pole and burn him or her. Therefore, inquisition was not a foundation that the public hated or detested at least at the beginning. In contrast, it was adopted by the public (Lecky, 1869, cited in Scot, 2001).

Now that we talk about torture, we should also mention Inquisition. Inquisition is a court for justice established by the Roman Catholic Church to suppress or to remove religion-based deviance. Clearly, torture was known as a tool for confession. Inquisitors almost turned torture into fine arts. The functioning of the system was designed in detail to break the resistance of a man even with the strongest willpower. In cases of slightly important crimes, the penalties included whipping, prisoning and sending into exile. However, in serious cases, the criminal, or the suspect, was tied to a pole and burned or sentenced to capital punishment. Most inquisitors were sadists (Scot, 2001). Examples of the tools used for torture can be seen below.

In Islamic belief, there is "torture" for those criminals. The 33rd verse of the MaideSurah in Qur'an says "The punishment for those fighting against the God and the Prophet is to kill or hang them, to cut their hands and legs, or to send to exile..." (Dursun, 2012).

According to the verses of the NurSurah, criminals deserve the punishment of "hitting with a stick 80 times (4th verse)" and "hitting with a stick 100 times (2nd verse)". Hitting a human with a stick "80 or 100 times" means torturing. In the AzhabSurah, it is said "Those tormenting religious men and women for a crime that they have not committed are certainly thought to fall into sin. The "torment" and "torture" in this verse means that criminals, not the innocent, deserve torture. 
In a world of people with quite different beliefs and thoughts, the notion of holy war, which aims at forcing all people to have the same thoughts and beliefs, allows anything to be done for the sake of spreading the religion of Islam all over the world.

\section{Torture Applied by the Governments}

Almost all European countries adopted the Roman law in Medieval Age and used torture to make people confess their guilt. In the 4th century, when Christianity became the formal religion of the Roman Empire, the emperors, who tried to preserve their civilizations by achieving unity of beliefs, used to apply torture as a method of discouraging deviants. ${ }^{2}$

Towards the end of the 13th century, legal torture became common in Italy as it was in the period of Caesar. It gradually spread to other countries, and in the 17th century, there was no European country considered torture to be an obligatory part of the punishment process (the only exception seems to be Scandinavia). In Germany, France, and Spain, legal torture became an inevitable part of the punishment system.

\section{Torture Museums and the Present Situation}

Museums are quite important and effective places for use to understand what kind of a creature human is. With its stairs and narrow paths as well as with its colors (red, orange, and blue), the torture museum I visited in Amsterdam was designed in a way to make you feel that you are as if you were in a prehistoric dungeon. The torture tools displayed in the museum were supported with various visuals and explanations written in different languages to show how they were used. The feeling of happiness and pleasure that generally occurs in art museums is replaced with embarrassment, restlessness, and sadness in torture museums. The fact that there is still violence in today's world reflects the fact that "the actual torture tool is the human himself". The report by the International Amnesty Organization in 2014-2015 demonstrates that all people are at risk of torture. ${ }^{3}$

The report by International Amnesty Organization in 2014-2015 states that there is still torture in 140 countries in the world. Political structures in governments apply torture on all people they consider to be a threat for them, and they regard torture as a legal tool.

The US Senate Security Intelligence Committee's report regarding the custody program of American Central Intelligence Agency revealed not the shocking details of the tortures applied by this organization but the extent of the connivance of European countries. Poland, Lithuania and Romania hosted secret custody centers. Some other countries like especially the United Kingdom, Sweden, Macedonia, and Italy helped the US government expose dozens of people under custody to illegal transfers, cruel treatment and torture. ${ }^{4}$

The European Union countries transfer individuals - which they consider to be threat to their own national security - to other countries where they are at risk of torture or cruel treatment. Throughout the old Soviet Union, the cooperative countries frequently transferred suspects wanted for terrorism to other countries in both legal and illegal ways where they were most likely to be exposed to torture.

In Syria, in the last four years, more than 200,000 people, most of whom were civilians, lost their lives as a result of the government's attacks. Approximately four million people are now refugees in other countries,

\footnotetext{
2 Retrieved from http://gizliilimler.tr.gg/.

3 Retrieved from http://amnesty.org.tr/.

${ }^{4}$ Retrieved from http://amnesty.org.tr/.
} 
and more than 7.6 million people have changed their accommodation places in Syria. ${ }^{5}$

In Gaza, during the 50-day gun battle which started on the 8th of July, the Israeli forces attacked houses, health centers and school sometimes in a way to kills a whole family. They consciously damaged houses and the civil sub-structure. In Gaza, more than 2,000 Palestinians were killed. Among them, more than 500 were children, and about 1,500 of them was determined to be civilians. Hamas and the Palestinian armed groups launched thousands of rockets and howitzers to the civil regions in Israel and killed six civilians, one of which was a child. In addition, the Hamas gunmen were accused of cooperating with Israel, and they killed 23 Palestinians who they brought out of the prison and who were not judged yet. ${ }^{6}$

In Middle African Republic, despite the international forces, more than 5,000 people were killed as a result of religion-based violence. The tortures, rapes and slaughters did not draw the world-wide press at all, and most of the people who lost their lives were civilians. Besides the violence applied by the government, there were other obvious tortures applied for the sake of religion (see Figure 1).

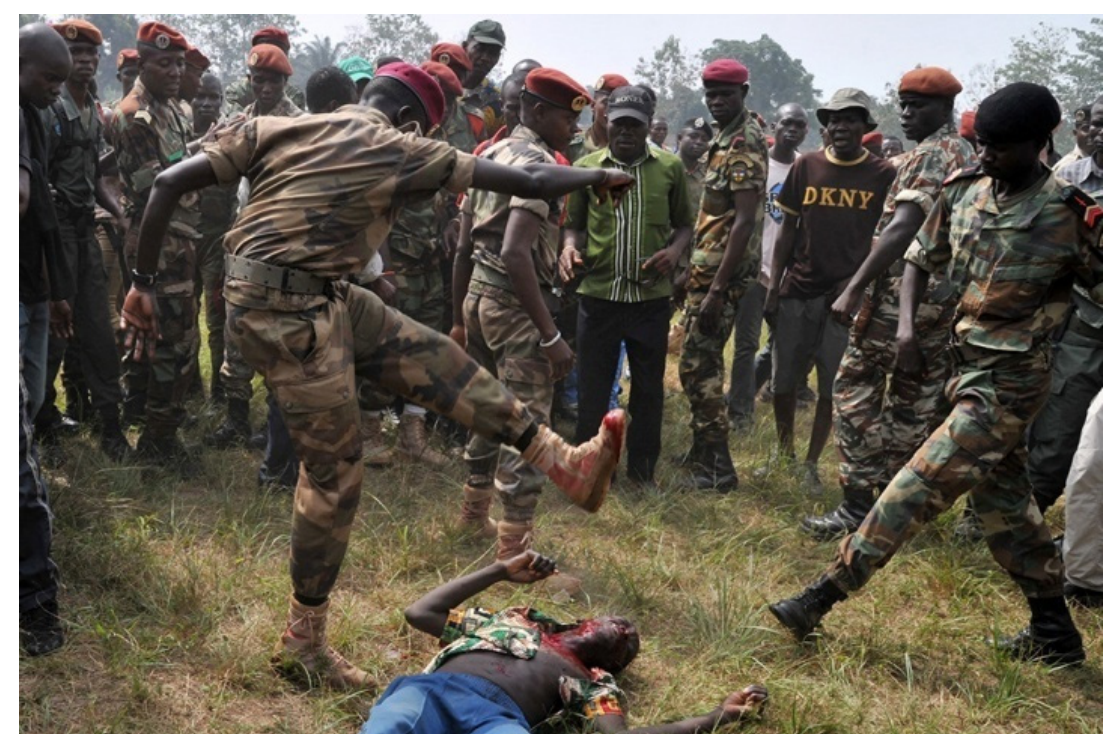

Figure 1. Enmity and genocide against Muslims in Central African Republic (Retrieved from http://www.thelight-asia.org/).

\section{Islamic State of Iraq and the Levant (ISIL) and Boko Haram}

Islamic State of Iraq and the Levant (ISIL) is a fundamentally religionist formation. To a great extent, ISIL is a center for young and middle-age adventurers who were raised without love and affection in Middle East, Asia and Europe. They punished those who violated the Islamic Laws in public by cutting parts of their bodies and whipping them in public. They kidnapped hundreds of Yezidi women and girls, used them as slaves and forced them to be a spouse of warriors of the Islamic State (IS) most of whom came from Europe, North America, Australia and from the Gulf countries. ${ }^{7}$

In contrast with those who killed people and tried to hide this crime, IS is quite cruel in all its actions. Newspaper reporters and international aid volunteers video-recorded the head-cutting of Lebanese and Iraqi

\footnotetext{
5 http://amnesty.org.tr/.

${ }_{7}^{6}$ Retrieved from http://amnesty.org.tr/.

${ }^{7}$ Retrieved from http://amnesty.org.tr/.
} 
soldiers or other violent actions. In Rakka and Eastern Halep, which were governed by IS according to its own Islamic laws; frequent executions of these cruel actions were done in public. First, the guilt of the suspects was declared. Then, they were shot with a gun, or their heads were cut mostly in public and even in front of children's eyes. According to a report by International Amnesty Organization ${ }^{8}$, most of these victims were male, but there also boys aged 15 and women among them (see Figure 2).

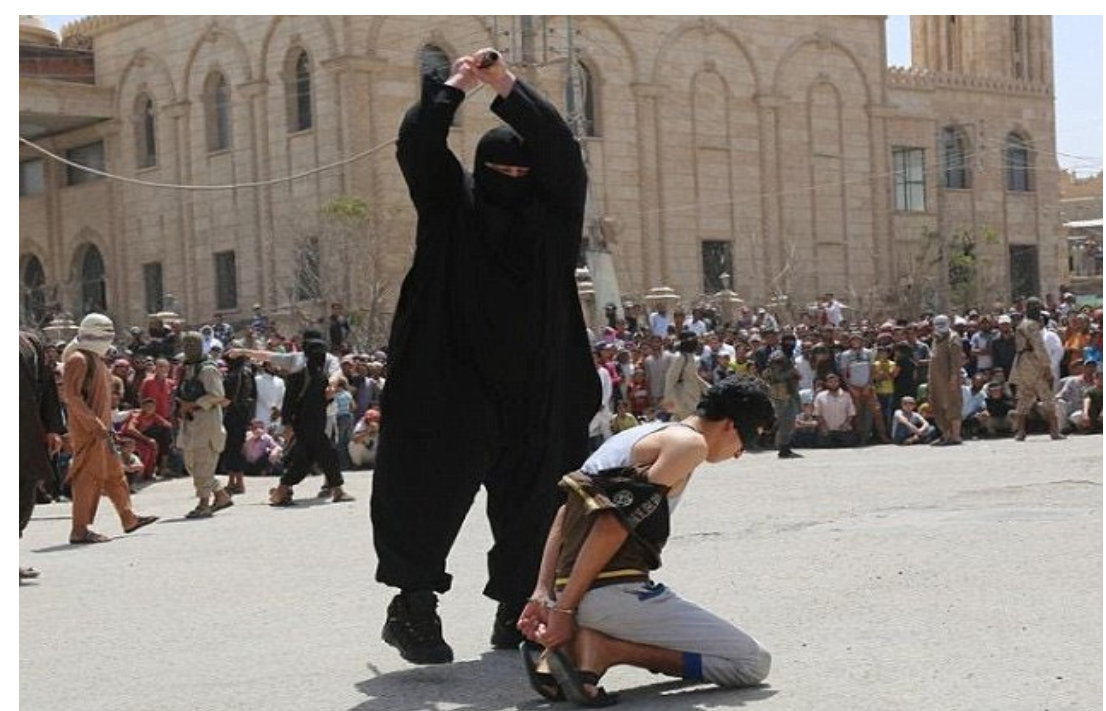

Figure 2. Most of the victims of IS were male, but there also boys and women among them (Retrieved from http://www.jihadwatch.org/).

In Tel Abyad, in the past one and a half year, those living under control of IS report that they are subjected to the strict religious applications of the organization. "They put me in the prison. Then I opened my eyes. We were five people in the room. There were people arrested because smoked, used slang words for Allah, kept his shop open during the religious Friday Prayer and used ISIL instead of IS". "They hit us with a hose or with a chain. They also used electric shock for those who they thought committed a more serious crime. I was hit with a hose several times" (Durgun, 2015).

"It thought my breasts smashed". According to a report published by the German newspaper Bild based on the statements of a victim, ISIL applies a kind of torture — known as "trap" —on women who did not wear in line with the Islamic laws in the city of Rakka in Syria. ${ }^{9}$

A woman called Batol, who was exposed to this kind of torture applied by ISIL said:

I was buying something in the market. The female members of ISIL came near me and said my face-cover was not appropriate to Islamic laws. They took me to the police center. They asked whether I would prefer whipping or the trap. I was afraid of whipping, and I didn't know anything about the trap. I thought it would make feel less pain, so I preferred the trap. They put and pressed my breasts between two metal things. I screamed. I thought my breasts were totally smashed. Then, they took me to a hospital. As far as I learned, they applied this type of torture on a number of women.

The female members of ISIL walk around in Rakka streets and check whether women wear clothes appropriate to Islamic laws. These female militants aged between 18-25 do not fight in the battle field, and most of them are from foreign countries (see Figure 3).

\footnotetext{
${ }^{8}$ Retrieved from http://amnesty.org.tr/.

9 Retrieved from http://www.mynet.com/.
} 


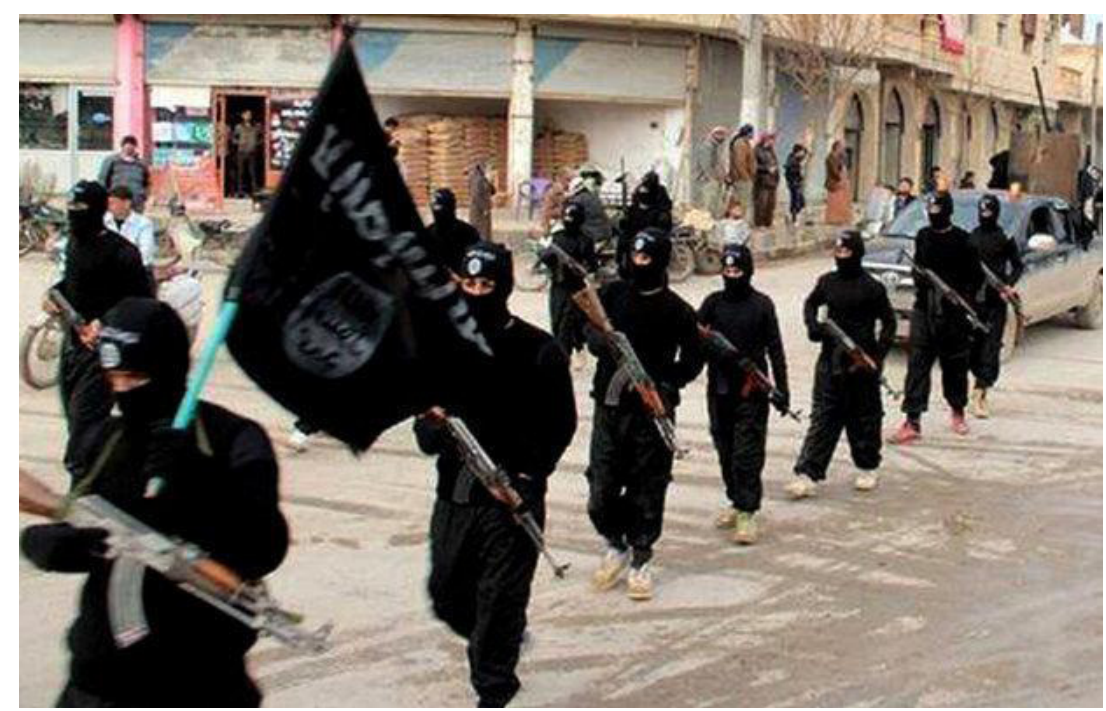

Figure 3. Most of the female members of ISIL are from foreign countries (Retrieved from http://www.dailystar.co.uk/).

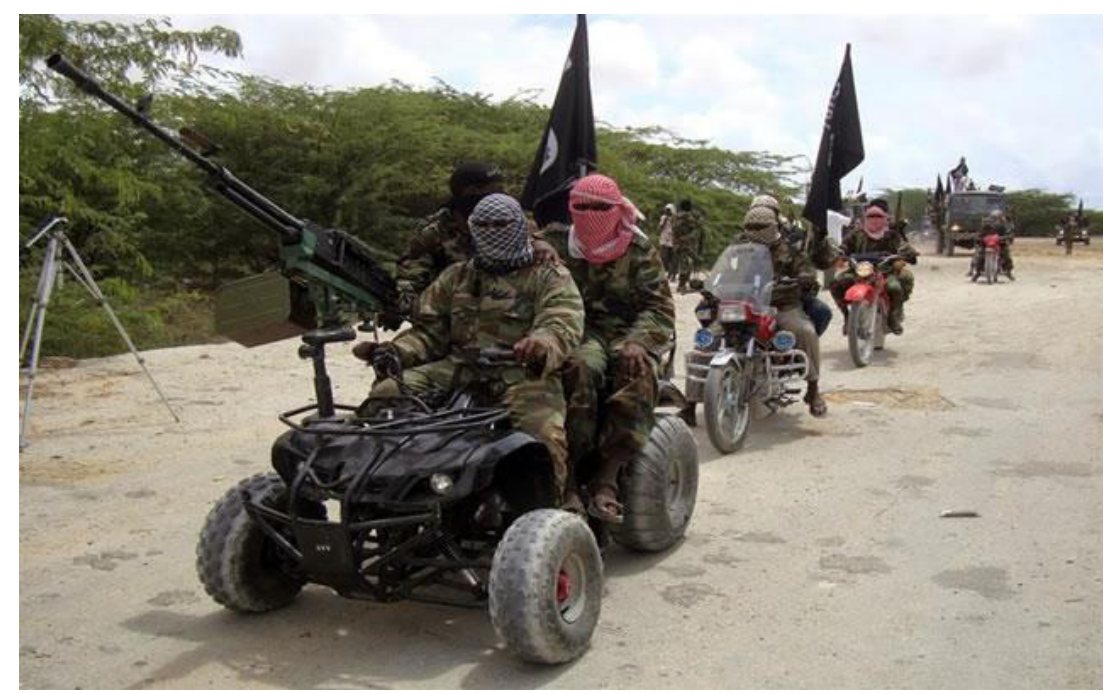

Figure 4. There are business contractors and politicians among the major financiers of the sect (Retrieved from http://headlines.ng/)

The philosophy of Boko Haram is rooted in the practice of orthodox Islam. Orthodox Islam in their interpretation abhors Western education and working in the civil service. This explains why the sect is popularly known as Boko Haram, literally meaning "Western education is a sin". Boko Haram actually means "Western Civilization" is forbidden. But the sect is opposed not only to formal Education coming from the West, but also to the whole Western culture. Its ideological mission is to overthrow the Nigerian state and to impose strict Islamic Sharia law in the country (Freedom \& Temilola, 2015).

Boko Haram draws the followers across the 19 states of northern Nigeria, Niger Republic, Chad and Sudan. Its members are mainly disaffected youths, unemployed graduates, and street children (Almajiris). As of 2010, Nigeria hosts about 9.5 million Almajiris, with over 80 percent concentrated in northern Nigeria. Besides Almajiris that form the bulk of its foot soldires, the sect also has as members some well-educated, wealthy and influential people such as university lecturers, business contractors and politicians who are the major financiers (see Figure 4). Recently, the sect added bank robbery to its sources of funds for meeting different needs: 
Helping the less privileged; sustaining the widows of those that died in the jihad; giving alms to the poor and needy; and for the prosecution of Jihad, among others.

\section{Tortureinstruments in Medieval Ages}

Torture used in Middle Age was legitimate, and there were different types of torture methods and devices in that age. The examples given below were among the more barbaric ones.

Pear of Anguish. This heinous contraption was used during the Medieval Ages as a way to torture women. It was also used to punish liars, blasphemers, and homosexuals. The device was inserted into one of the prisoner's orifices - the vagina for women, the anus for homosexuals, and the mouth for liars and blasphemers (see Figure 5). The device featured four metal leaves that slowly separated from each other as the torturer turned the screw at the top. ${ }^{10}$

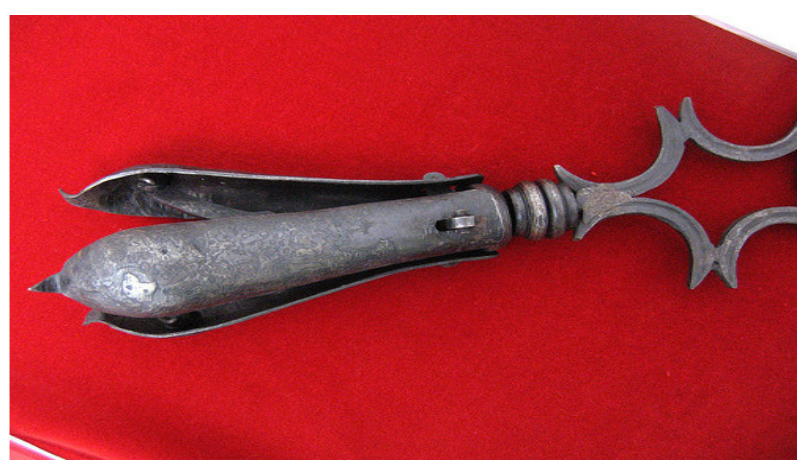

Figure 5. Pear of Anguish.

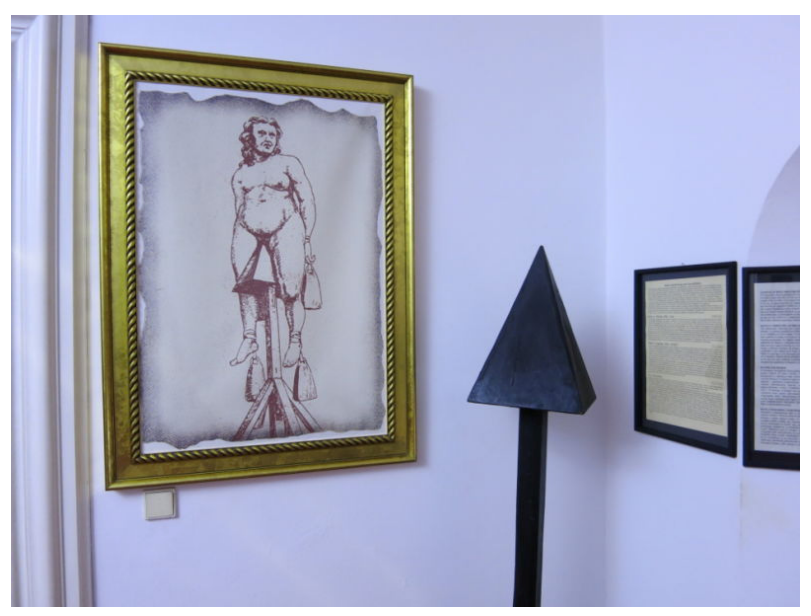

Figure 6. The Judas Chair.

The Judas Chair. Using ropes, a prisoner would be lowered above the pyramid-shaped "seat" with the point inserted into the anus or vagina (see Figure 6). Victims would be tortured by intense pressure and stretching of the orifice, resulting in permanent damage. In many cases, the victim would succumb to rips in the muscle tissue that would later become infected. Weights would be added to facilitate the effect, often resulting in death by impalement. ${ }^{11}$

\footnotetext{
${ }^{10}$ Retrieved from http://io9.com/

11 Retrieved from http://io9.com/.
} 


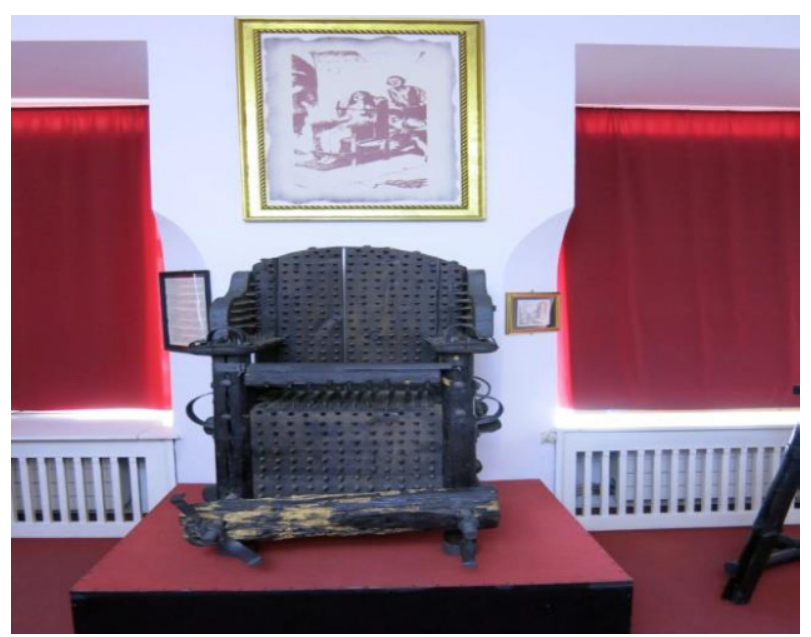

Figure 7. Iron chair.

Iron chair. This torture device was used extensively during the Medieval Ages. Victims would be placed onto the chair-which featured hundreds of sharp spikes - followed by the progressive tightening of iron restraints, forcing the spikes deep into the flesh (see Figure 7). This could go on for hours, sometimes days. The spikes did not penetrate vital organs and blood loss was minimized - at least until the person was released from the chair. Death often followed. The Iron Chair was often used as a psychological instrument of torture; victims would often confess after being forced to watch other prisoners being tortured by the device. ${ }^{12}$

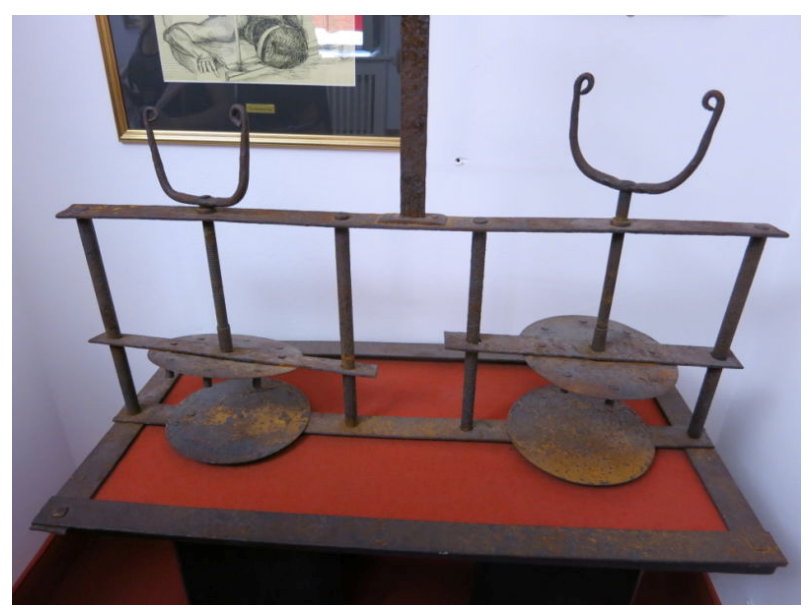

Figure 8. Head crusher.

Head crusher. The device, which is basically a vise for the head, slowly crushes the skull and facial bones. Even if the torturer stopped before death, permanent damage to the facial muscles and structure would occur. ${ }^{13}$

Breast ripper. This instrument is known as the breast ripper or Iron Spider, it was mainly used on women who were accused of adultery, self-abortion, heresy, blasphemy, or accused of being witches. It was also used for interrogations. The device, which was often heated during torture, contained four "claws" which were used to slowly and painfully rip off the breasts. ${ }^{14}$

\footnotetext{
${ }_{12}$ Retrieved from http://io9.com/.

13 Retrieved from http://io9.com/.

${ }_{14}$ Retrieved from http://io9.com/.
} 


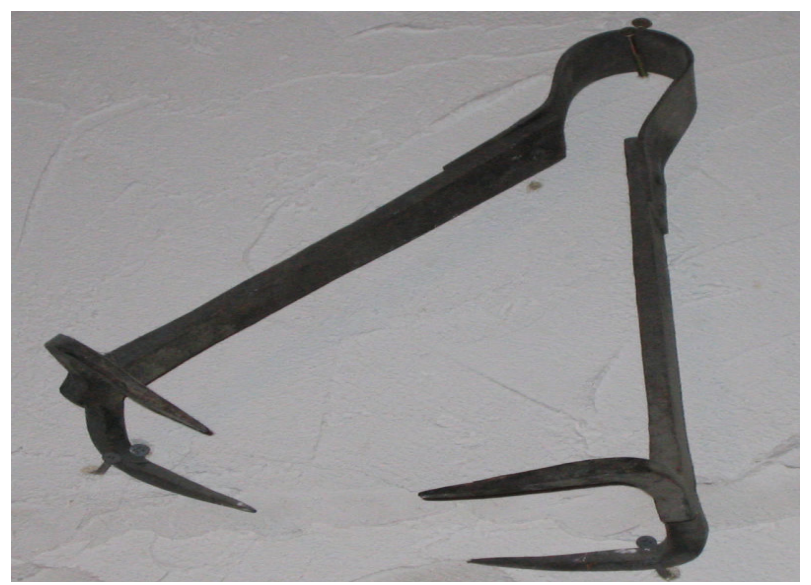

Figure 9. Breast ripper.

\section{Final Words}

It is doubtful whether sacrificing an animal is prior to sacrificing a human. However, in history, there is no doubt that the following types of torture were applied: burning with a boiling iron, burning after being tied to a pole, giving electrical shock to the genital organs, cutting such parts of the body as the tongue and genital organs, beating violently, hanging from the legs with hands tied at the back, removing the nails, pricking under the nails, pulling the teeth without using any anesthesia, waiting in the position of " $Z$ " for hours, putting the head in water, giving water from the mouth, making deprived of foods and water, and making sleepless (Stanford Encyclopedia of Philosophy, 2011).

It is seen that torture has been generally applied for patriotism, for religious purposes and for the sake of the government. However, in ideological sense, there is no difference at all between religion and patriotism. The Yurtsever, in its most comprehensive meaning, is in the same position as the radical religionist is at war time or under the conditions of war threat. The deviances about one's own country or race lead to hatred towards the opponent or the enemy country or race. Appearance of torture or cruelty is especially probable at such times.

When the problem is viewed from the perspective of individuals, the fact that violence still exists in today's world clearly indicates that "the main torture tool is actually the human itself". It is an undeniable fact that there are individuals who enjoy watching scenes involving cruelty or pain. Sadists like demonstrating cruel attitudes or witnessing such a situation, but their pleasure with this is only associated with sexual provocation or relaxation.

In line with the changes in people's lives, there has been a change in the way of sadism. Pure physical sadism has been replaced by a more indirect and moderate sadism. At first glance, the gladiator fights and gymnasium competitions in Ancient Rome seem to be quite different from today's circuses and boxing matches, but actually, they are essentially similar.

Another dimension of the problem is that most people who voluntarily kill or torture other people are either radical religionists who are ready to feel pain to become a martyr on the way to reach their God instead of finding peace in this world or masochists who enjoy physical pain.

It is impossible for a tormented individual to prove his or her innocence following a torture. The reason is that the only purpose of the torturer is to justify the torment and to punish the suspect. The confession does not 
necessarily reflect the truth. Therefore, in terms of justice, the process is not fair or useful for revealing the truth.

\section{References}

Defining torture. (n.d.). Retrieved from http://www.irct.org/

Durgun, H. (2015). IŞSiD'in Tel Abyad'daki cezaevine girenler anlatıyor: 'Isşkence gördük' (Those who have been put into ISIS's jail in Tel Abyad tell: “We are tortured”). Retrieved from http://www.bbc.com/

Dursun, T. (2012). İslamda İskence (Torture in Islam). Retrieved from https://www.turandursun.com/

Freedom, C. O., \& George, T. A. (2015). Boko Haram's use of Female Suicide Bombing in Nigeria. Retrieved from http://studies.aljazeera.net/

Gizli Emir ve Tarihin Karanlı Sayfalarl (Secret Order and the Dark Pages of History). (n.d.). Retrieved from http://gizliilimler.tr.gg/

ISIS report Shows Brutality Against Women and Young Girls. (n.d.). Retrived from http://www.christianpost.com/

IŞID'den kadınlara akıl almaz işkence yöntemi (Unbelivable torture method from ISIS to women). (2015). Retrieved from http://www.mynet.com/

Lecky, W. E. H. (1869). History of European Morals from Augustus to Charlemagne. In G. R. Scot (Ed.), The History of Torture Throughout the Ages (p. 72). Retrieved from http://www.metaphysicspirit.com/

Medieval Torture. (n.d.). Retrieved from http://www.medievalwarfare.info/

Men, women and children as young as 12 have been victims of torture in Nigeria. (n.d.). Retrieved from http://www.rightnow.io/

Scot, G. R. (1959). The history of Torture throughout the ages. Retrieved from http://www.metaphysicspirit.com/

Scot, G. R. (2001). İskencenin Tarihi (The History of Torture). Ankara: Dost Kitabevi yayınları.

Stanford Encyclopedia of Philosophy. (2011). Torture. Retrieved from http://plato.stanford.edu/

Sumner, W. G. (1907). Folkways. In G. R. Scot (Ed.), İşkencenin Tarihi (The History of Torture) (p. 26). Ankara: Dost Kitabevi yayınları.

Uluslararası Af Örgütü Türkiye Şubesi (Turkish Branch Office of Amnesty International). (2015). Uluslararası Af Örgütü Raporu 2014/15 (Amnesty International Report 2014/15). Retrieved from http://amnesty.org.tr/ 